\title{
PROLETARIANISATION, AGENCY AND CHANGING RURAL LIVELIHOODS: \\ FORCED LABOUR AND RESISTANCE IN COLONIAL MOZAMBIQUE
}

Bridget O'Laughlin

December 2001

Working Paper 354

\footnotetext{
* This paper draws heavily on work done by researchers at the Centro de Estudos Africanos, Eduardo Mondlane University. I would also like to thank those who gave helpful comments on an earlier draft presented at the Workshop on Multiple Livelihoods and Social Change in the Institute for Development Policy and Management, University of Manchester, and to the Rural Development Seminar, The Institute of Social Studies.
} 
The Institute of Social Studies is Europe's longest-established centre of higher education and research in development studies. Post-graduate teaching programmes range from six-week diploma courses to the $\mathrm{PhD}$ programme. Research at ISS is fundamental in the sense of laying a scientific basis for the formulation of appropriate development policies. The academic work of ISS is disseminated in the form of books, journal articles, teaching texts, monographs and working papers. The Working Paper series provides a forum for work in progress which seeks to elicit comments and generate discussion. The series includes the research of staff, $\mathrm{PhD}$ participants and visiting fellows, and outstanding research papers by graduate students.

For further information contact:

ORPAS - Institute of Social Studies - P.O. Box 29776

2502LT The Hague - The Netherlands - FAX: +31 704260799

E-mail: workingpapers@iss.nl

ISSN 0921-0210

Comments are welcome and should be addressed to the author: 


\section{ABSTRACT}

In current analytical approaches to rural poverty in southern Africa, the concept of changing livelihoods stands in an inverse relation to the concept of proletarianisation. The more we see the term livelihoods, the less we see proletarianisation. This shift reflects criticism of Marxist work on proletarianisation for its teleology - confusing irreversibility with inevitability - and for its functionalism - not recognising the agency of the poor, including the struggles of people not to be proletarianised. It also reflects, however, the current ascendancy of methodological individualism in development studies. This paper argues that much is lost when the description of livelihoods becomes an alternative to class analysis rather than its complement, and when agency is reduced to individual strategising. It argues that the multiplicity and variation of rural lives in Mozambique today are the outcome of a historical process of proletarianisation grounded in recourse to forced labour by capitalist enterprises and the colonial state. It shows how both forced labour and resistance to it shaped the ways labour and agricultural commodity markets worked and developed. The concept of changing livelihoods helps us to us to document the processes of commoditisation that underlie both the contingency of proletarianisation and its irreversibility. It thus also helps us to understand why the struggles of rural people against forced labour and forced cropping often brought them more tightly into a world where wagelabour was done or hired. If we become so enmeshed in documenting the complexity of multiple livelihoods and individual creativity that we can no longer see broad patterns of class struggle in historical change, then the concept of livelihoods becomes an ideological mask rather than a useful working tool. 


\section{CONTENTS}

1. Shifting Visions: From Proletarianisation to Multiple Livelihoods .................1

2. Agency as Strategy: the Dislocation of Class ............................................ 3

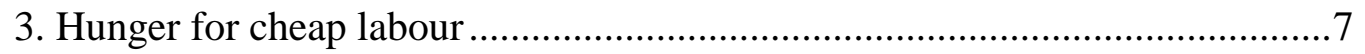

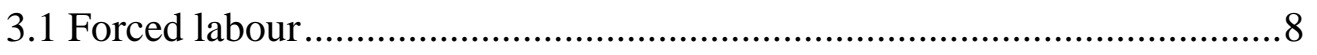

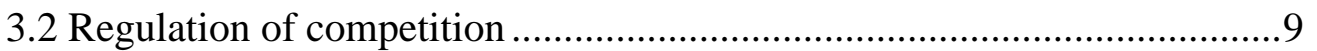

3.3 The interdependence of markets: forced and free, labour and commodity 12

4. Resisting Shibalo and Forced Cropping ............................................ 15

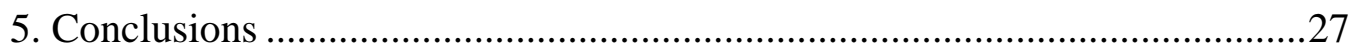

Appendix .............................................................. Error! Bookmark not defined.

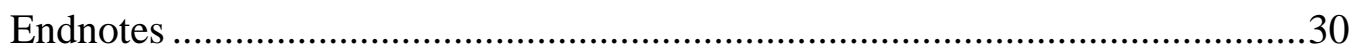




\section{SHIFTING VISIONS: FROM PROLETARIANISATION TO MULTIPLE LIVELIHOODS}

Over the last twenty years, our vision of the impact of labour migration in rural areas in Southern Africa has shifted radically. In the mid-1970s we saw imperialist regimes carving up the countryside into labour reserves and using political instruments - taxation, forced labour and collusion with pre-capitalist elites - to force young men to migrate to work for a pittance. We saw WENELA/TEBA agents scattered across the region contracting cheap labour. We saw the subsistence production of women in rural households producing the labour-power of these migrant men (thus subsidising the wage that made rapid accumulation of mining capital possible). We saw rural areas as a refuge that absorbed the old, the incapacitated, and, in moments of market crisis, the temporarily unemployed. We saw a process gradually undermining its own conditions of existence as rural families became increasingly dependent on commodities, and thus monetary income, both for current consumption and for financing investment in their own agricultural production. In short, we saw a rapid process of proletarianisation and differentiation driven by structural processes of accumulation of capital.

From the mid-1980s onwards, the causes, patterns and consequences of labour migration for rural life have appeared more contingent and contradictory. We no longer see capital hungering for cheap unskilled labour, but rather mine redundancies and rural

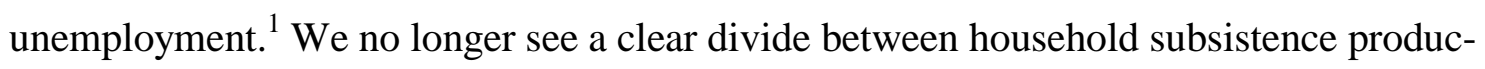
tion and migrant wage-labour. Rather we see people in rural households combining food production with diverse ways of generating income - brewing, making charcoal, repairing shoes, queuing for food aid, doing casual wage-labour, receiving remittances and pension payments, selling livestock. We see no an emerging class opposition between a landless rural proletariat and commercial farmers (black or white), but rather people earning their livelihoods in diverse ways. Some households combine doing wage-labour with hiring wage workers for their own fields for commercial production; others live from relief and petty trade, others reside in the countryside but depend almost entirely on earnings from wage employment, investing not in cattle but in the education of children or in a good house. Households are themselves now seen to be unstable units rather than corporate groups. We follow individual members of households with diverse gendered resources and constraints pursuing their own livelihood strategies, which may not conform to the interests of other household members. Men, women and children may float through various house- 
holds drawing on and contributing to household livelihoods, coping with insecurity in diverse and unpredictable ways. In short, we talk about multiple livelihoods, or even deagrarianisation, but we rarely mention the term 'proletarianisation.'

Cramer and Pontara have recently made an attempt to counter this analytical trend for the case of Mozambique. Relying mainly on evidence from Gaza, a southern province, they argue that literature on rural poverty in Mozambique pays too little attention to the existence and interests of poor rural wage-workers on the one hand and to the conditions of accumulation of agrarian capital on the other. In a critical response, Pitcher contends that Cramer and Pontara rely on figures that exaggerate the control of capitalist enterprises over commercial land, do not attend adequately to regional differences that tied rural families in northern Mozambique to cash-cropping rather than migrant labour, and underestimate the overlapping multiple livelihood strategies in which control over land remains important even for those who are rural wage-workers. ${ }^{\text {B }}$ She argues against the image of sharpening class divisions implicit in the idea of proletarianisation.

The pressures that the countryside in Mozambique is facing do not lend themselves easily to either/or approaches such as wage labour versus land, companies versus smallholders. Rather, the challenges are fluid and intricate, historically derived and differentiated by region, by method of production, by status and by economic position. Future research needs to recognise and disaggregate this complexity.

Whereas Cramer and Pontara see broad historic patterns of proletarianisation and accumulation of capital reflected in the lives of rural women, Pitcher emphasises regional differences in history and the need to even further disaggregate the complexity of rural livelihoods. Marxist structural analysis of rural change and rural poverty are displaced by an actor-oriented strategic approach towards understanding rural poverty.

In detailed description of rural livelihoods, Pitcher is on firm ground. Cramer and Pontara would be wrong to assume that the impoverished women agricultural workers they interviewed in Gaza are an important social category in all areas of the country. Figure 1 in the appendix, drawn from the 1997 census data, shows differences in sex-ratios across rural adult age-groups, and thus indirectly the extent of labour migration, between Gaza, a southern province, where Cramer and Pontara interviewed women farm workers, and Nampula, a northern province where Pitcher has done research.

What is troubling in Pitcher's response, however, is the now familiar counterposing of a careful analysis of livelihoods to class analysis, and the corresponding methodological emphasis on documenting complexity. Cramer and Pontara address a reality which further 
disaggregation of complexity will never allow us to see: the relationship between long-term structural processes of accumulation of capital and the historically and regionally diverse ways in which rural people combine various ways of working to produce their livelihoods. Entangled in the documentation of everyday life, we can miss the fact that proletarianisation is also real, a historical process that while not inevitable is also irreversible in Southern Africa.

This paper argues that if we wish to understand multiplicity and variation in rural livelihoods today in Mozambique, we need the concept of livelihoods, but only if it embedded within an understanding of proletarianisation, rather than within an alternative framework of livelihood strategies. This means understanding the present as an ongoing historical process, and thus returning to the colonial period to attend to the ways in which the forced labour regime revolutionised rural livelihoods. In developing this argument, the paper draws on a substantial body of Marxist work on proletarianisation in Africa - and on the equally substantial body of criticism of it, particularly that of the historians of resistance. Before addressing the case of Mozambique, it is therefore useful to look at this work, and its implications for the ways in which we understand rural livelihoods today.

\section{AGENCY AS STRATEGY: THE DISLOCATION OF CLASS}

Emphasis on complexity, multiplicity and individual livelihood strategies is in part a critical reaction to teleology and functionalism in Marxist scholarship in southern Africa. We were so convinced, it is said, that African peasants were on march towards the proletariat $^{\mathrm{b}}$ that we could not see anything else. We were so concerned with showing the exploitative power of capital and the state during the colonial period that we robbed African peasants and workers of agency, their distinctive histories, and their cultural identity. Much of this criticism is justified and backed by research.

Current research, like that of Pitcher, emphasises the complexity of rural class structure and the contingency of proletarianisation. It is no longer assumed that there is a continuous homogeneous pattern of increasing proletarianisation based on the cheap labour policies of apartheid, or that the decline of non-wage contributions to household subsistence is inevitable. Detailed case-studies on colonial Zimbabwe, such as Ranger's work on Makoni, have suggested that colonial occupation and alienation of land did not necessarily lead to the destruction of peasant production. ${ }^{6}$ Historical work on farm labour in Southern Africa shows no clear irreversible movement towards wage-labour. Within a single district 
or even on a single farm wage-labour could co-exist with share-cropping and tenancy; farms that used principally wage-labour at one point could revert to tenancy arrangements and back again. Moore and Vaughan in their historical study of the Bemba labour reserve area of Zambia show that cash-cropping has had a healthy revival. ${ }^{\text {G }}$

Consistent with its emphasis on the inevitability of proletarianisation, Marxist work in southern Africa sometimes privileged workers' struggles and consciousness (particularly in South Africa), assuming the ideological and organisational backwardness of the peasantry. Beinart and Bundy showed that by the 1920s rural struggles in South Africa reflected the complexity and diversity of rural lives. . $_{\text {They were not just isolated populist rebellions }}$ against power, but instead linked communities, even bridging at times the rural/urban divide. Ranger argued both that there was a distinctive peasant consciousness in Zimbabwe, and that it had been deeply enmeshed in the struggle for independence. ${ }^{9}$

Marxist historiography in Africa has also been criticised for its functionalism - assuming that what endures can only do so because it reflects the interests of capital, or that capital always accumulates. If pre-capitalist forms of lineage organization and customary tenure survived, it was because capital needed cheap labour-power. The colonial state was assumed to be a rational and nearly omnipotent instrument of capital. Marxist studies, based on work such as Rey's powerful analysis of the violence of French rule in Congo Brazzaville, ${ }_{10}$ concluded that violence of colonial rule was a necessary condition for the penetration of capitalist relation of production in Africa. The corollary of this position was the privileging of the state in political analysis, with relatively little attention to the politics of everyday life.

Subsequent studies emphasise both that colonial governments could be contradictory and feeble in their promotion of capitalist interests and that wage-labour and commodity production predated colonial rule in some areas. Historians of resistance have argued that proletarianisation was not inevitable in Africa in part because rural people did not want it to be. They showed workers and peasants evading, mocking, and sabotaging those who exploited them. ${ }^{11}$ Cooper documented the importance of struggles by migrant workers not to become a class, to invest at home, to maintain independent production. Isaacman argued that in stressing the devastating effects of commodity production on African communities, Marxist scholarship on cotton production in Mozambique reduced all cotton growers to victims, neglecting the ways in which they coped with and struggled against the cotton regime. ${ }^{13}$ We reduced history, that is to say, to the logic of capital. 
Much of the critical work on resistance is historically rich and nuanced. Nonetheless, the weaknesses and lacunae it has identified in Marxist research on southern Africa are not sufficient to explain the current infrequency of references to class in discussions of rural poverty nor why the concept of livelihoods has come to efface rather than to complement that of proletarianisation. Scholarship proceeds through critical exchange; much of the best of this research addressed a Marxist problematic. Teleological functionalism is not consistent with an analytical emphasis on contradiction and class struggle, and thus not inherent in a critical Marxist perspective. Indeed the work of the resistance historians was inspired by Hobsbawm's Primitive Rebels and that of Aptheker, Foner and Genovese writing on slavery. ${ }^{14}$ Marxist historians saw exploitation and oppression as inherently conflictful. Thus resistance did not have to be explained; rather it was the ways that it was expressed, confronted or suppressed that were of interest.

The explanation of the proletarianisation/livelihoods opposition lies elsewhere, in the apparent post-socialist condition and the related ascendancy of micro-economic methodological individualism within the social sciences in general and within development studies in particular. $\frac{15}{15}$ This ascendancy is reflected in the slippage from a descriptive concept - livelihoods - to an explanatory one - livelihood strategies. The livelihoods framework now employed widely in development studies (and in the linked area of development cooperation) has at its centre strategising individuals, equipped with variable portfolios of material and non-material assets, attempting to employ them in ways that maximise their own preferences and priorities, in an environment of risk and uncertainty. ${ }^{6}$ Like Amartya Sen, upon whose entitlements and capabilities approach they draw, the designers of the Sustainable Livelihoods Frameworks have attempted to disrupt the neoliberal consensus by introducing issues of equity and vulnerability couched in the language of neo-classical economics. ${ }^{17}$ Class is present, but only as context, one among many complex historically derived institutions that shape the unequal distribution of assets, capabilities and opportunities.

This is a very reduced vision of agency, power and history. Within the livelihoods framework, structure is the contingent outcome of micro-processes of decision and thus analytically redundant. The specificity of capitalist class relations is effaced as social networks become possessions, possessions become assets and assets become capital. The concept of class struggle, with its emphasis on collective agency, confrontation and political power, is replaced by concern for the affirmation of individual agency and identity, 
understood in terms of strategising, preferences, priorities and choice. Agency is reduced to individuals strategically choosing among options so complex that they remain largely outside anyone's control. The legitimacy of revolutionary political agenda, positing radical rupture with existing class relations, has yielded to concern with poverty reduction programmes that pretend to make it easier for individuals to cope by increasing or protecting their assets, entitlements and capabilities. The social world is, universally and eternally, a market. For the poor, there is creative coping, and affirmation of self-worth (identity and dignity), but no class struggle.

This paper attempts to detach the concepts of livelihoods and resistance from the micro-economic language of possessive individualism and strategic gaming and to reclaim them for a Marxist terrain of class struggle. It argues that only by reintroducing explicit analytical concern with long-term structural processes and the dialectical relationship between exploitation and resistance can we understand the options that rural people in Southern Africa confront today as they piece together their livelihoods in diverse ways that may or may not include wage-labour. Coercion and exploitation shaped changing livelihoods, but so also did the struggles of peasants and workers against them. In resisting forced labour, Mozambican women, men and children were most often trying to protect their livelihoods; they seldom affirmed anything as abstract as class. Yet these struggles often had outcomes they neither predicted nor chose, including a deeper involvement in capitalist relations of production, that is, proletarianisation.

In approaching the historical forces that shape multiple livelihoods in Mozambique today, the paper begins not with worker and peasant struggles, but with those of capitalist enterprises for profit. This is the world from which micro-economics draws its analytical concepts: competing and maximising agents mobilising social and political networks to enlist the resources of the state. But it is also a world rent by the fundamental political divide from which micro-economics abstracts - the basic relation of exploitation between capital and labour. The section traces how, by law and violent coercion, employers and the colonial state used forced labour to restrict the ways in which colonised subjects could construct their livelihoods. The paper then turns to the other side of the dialectic: practices of resistance by rural people to forced labour and the consequences these had for where and how they worked. 


\section{HUNGER FOR CHEAP LABOUR}

In Mozambique, as elsewhere in Africa, historical studies do not strictly support the interpretation that colonial rule was necessary to unleash a process that took subsistence-oriented production and refashioned it through taxation and violence into production for exchange. In the $19^{\text {th }}$ century, before the gradual extension of effective Portuguese occupation, young men were tramping to the plantations of Natal and the diamond and gold mines of South Africa ${ }^{[18}$ Food crops and oil seeds produced by peasants moved out of ports in Northern Mozambique and supplied coastal settlements in the19th century Forms of labour recruitment and migration in the $20^{\text {th }}$ century strongly resembled pressganging of workers and export of labour by prazo holders in central Mozambique after the formal abolition of slavery in 1879 .

Yet, to stress continuity between pre-colonial and colonial worlds is to belie the scale and range of expansion of capitalist enterprises within the southern African region and the corresponding sharp demand for Mozambican labour in the $20^{\text {th }}$ century. Mines in South Africa, Rhodesia, and even the Congo recruited Mozambican migrant workers. The colonial authorities were under pressure to grant recruitment rights to the French Indian Ocean colonies and to Sao Tome cocoa planters, and themselves needed manual labour for public works. 21 New agricultural enterprises recruiting Mozambican field labour were established: multinational and British owned plantations of sugar, copra and sisal on the coast and inland along the great river valleys, highland tea estates in Malawi and Zambezia, settler farms producing food for domestic markets. Railroads and busy ports, linking Lourenco Marques and Beira to exporters in South Africa, Rhodesia and Nyasaland, were built and operated by Mozambican workers. Cotton was developed as a new cash-crop with concessionary companies opening ginning factories throughout the country in the 1940s. Portugal imported only 190 tonnes of baled cotton fibre from Mozambique in 1930, and 39718 tonnes in $1960 .{ }^{22}$ Urban industries recruited Mozambican workers, as well as better paid Portuguese settlers.

Many of these enterprises were speculative ventures, operating in conditions of precarious profitability. Plantation and mining capital faced the booms and busts of international export and financial markets. ${ }^{23}$ Portuguese-owned farms faced competition from more productive and established fruit, vegetable and maize farms in Rhodesia, and South Africa. ${ }^{24}$ After attempts to establish cotton as a settler plantation crop had failed, a 1926 consultant's report suggested that ecological conditions for cotton production were, con- 
trary to expectations, poor in Mozambique. All pressured the colonial governments of the region for guarantees of profitability, for assistance in labour recruitment, and for monopsony over labour to drive wages down and keep them low. Portuguese capital was particularly weak relative to other regional capitals. Labour export was criticised by the settler press and by pressure groups of white employers, but the self-financing basis of the colony depended heavily on taxes derived from labour export. 26

Portuguese colonial authorities responded to these competitive demands in two ways: first, they resorted to forced labour, both to recruit workers unwilling to accept jobs under conditions on offer and to drive down wages across the sector; second they attempted to regulate competition among the various sectors of capital.

\subsection{Forced labour}

Until 1961, under the labour codes of the Indigenato, 'citizens', Portuguese or assimilated, were those who retained the right to determine where, how and under what conditions they worked. All able bodied men defined as 'native' were obliged to work, an obligation considered satisfied only if they had capital sufficient to live off the income, or exercised a profession, or cultivated fields of a size fixed by statute, or produced export crops in specified quantities, or did wage-work for a minimum period B fixed at six months per year. ${ }^{27}$ Women were initially assumed to have a productive role in agriculture or in the domestic economy. Men over 60 and under 14 years were exempt, as were the ill, infirm, police and customary officials. Under the Indigenato, there were two forms of forced labour, impressment, known as shibalo, ${ }^{6}$ and forced cropping.

Shibalo included different forms of impressment. Men not satisfying conditions of exemption were impressed for migrant labour. A small wage was paid when they returned to their home areas, having satisfactorily completed their six months of work. Both men and women were impressed for undefined periods of public service to the state, as for road or rail construction. Both men and women were impressed for variable periods of punitive labour for non-criminal offences such as not paying one's tax, or escaping from contract labour. Penal labour was also used for public works and let out to private employers. Offences under the forced labour system could be punished by whipping, by penal labour, or by deportation to the plantations of Sao Tome.

In the 1940s, the forced labour legislation was extended to forced cropping, obliging peasants, both men and women, in particular areas, to satisfy their obligation to 'work' 
by cultivating, usually on their own land, cotton or rice for obligatory sale to a concession holder. Within households, particularly in central Mozambique, the two kinds of obligation sometimes overlapped. Men were recruited for plantation labour while women were obliged to cultivate cotton.

Coercion under the forced labour legislation was supported by the other institutions of the Indigenato: access to land under customary tenure, local governance through customary chiefs (regulos), and the pass system. 1918 (as elsewhere in southern Africa about the same time), a land law was passed establishing native reserves, where white settlement was not allowed, where land could not be bought and sold, and where control over land was vested in customary officials or chiefs - regulos. Access to land for cultivation did not prevent workers from demanding higher wages, but it did mean, as Meillassoux 3 and others insisted, that employers did not have to pay a subsistence wage. Limits on freehold also impeded the development of Mozambican commercial farmers who might have competed for labour.

Everyday administration of the forced labour system depended on customary chiefs and their police. District administrators received requests for labour and apportioned recruitment quotas to the different regulos under their jurisdiction. Regulos negotiated with lineage heads in their territories to identify those who would be recruited. Despite the sixmonths provision of the law, many worked successive contracts. Regulos also assured the payment of taxes out of the migrant worker's deferred wage.

Restriction of personal movement under the pass system was used to enforce labour codes in Mozambique and to prevent employers throughout the region from hiring workers who had fled from another farm, mine or contractor. Men, women and children required an express authorisation from the colonial administration for any change of residence or movement beyond their area of origin. Men of productive age had to pay for and carry a native identity card, as did adult women living in administrative centres or towns. The pass system was gendered, restrictions on the movement of women and children were tighter than for men; women required the authorisation of their husbands or male elders of their household as well as that of local authorities to move.

\subsection{Regulation of competition}

To use force repetitively would have been costly, both economically and politically. The Portuguese administration was in some areas thin on the ground. ${ }^{64}$ Coercion 
complemented state regulation of competition among employers and traders to make it difficult for workers and peasants to seek higher wages, prices or conditions of employment.

A regional division of labour in labour recruitment was negotiated through international agreements with South African and Rhodesian colonial authorities and accords between the state and enterprises within Mozambique. Conflicts between South African mining capital and other mining and plantation capital across the region led to drawing a line at the $22^{\text {nd }}$ parallel, in Mozambique roughly along the Save River. South of the Save, South African mining companies competed only with settler farmers for labour. North of the Save they could not recruit; plantations in Mozambique would thus compete only with the mines and farms of Rhodesia for labour recruited from central Mozambique and Malawi. In 1948, the state cotton agency introduced the 'farmer's card' which protected the bearer from forced labour if he were assiduously cultivating cotton, thus reducing ad hoc recruitment of plantation and mine labour in northern Mozambique. Although there were coastal sisal plantations in the North, settlement was discouraged until the 1960s, and hence presented no competition with cotton for peasant labour. Thus was established the pattern of regional variation in forms of exploitation that still marks rural class structure today in Mozambique: mine labour in the south, plantation labour in the centre, and smallholder cotton in the north.

The regional division of labour was renegotiated over time. In the 1950s, the JEAC, the state cotton board, surveyed the potential of all cotton-growing areas in Mozambique and recommended the extension of cotton in some areas and its withdrawal from others. ${ }^{6.5}$ Criteria were not purely agronomic. The northern part of Alto-Molocue in Zambezia district, for example, was to be withdrawn from cotton cultivation. It was an area of recruitment for the tea plantations and could potentially be a food marketing area at a time when plantations were having difficulty acquiring rations cheaply. In 1958, when the Zambezi plantations were losing workers to Rhodesia, and the Rhodesian colonial government was beginning to worry about rural unemployment, recruitment of Mozambicans was legally abolished, though clandestine flows did not stop.

The colonial government collaborated with large capital to reduce competition for labour and to hold down prices paid for peasant crops. The South African Chamber of Mines was allowed to set up a common recruitment service, WENELA, for both gold and coal mines with offices in rural areas in southern Mozambique. Runners were sent out from 
these offices to inform the regulos about recruitment needs. ${ }^{36}$ When tea production expanded in Upper Zambezia, small producers were pressured to join a gremio that regulated offences such as hiring workers who had deserted from another plantation. 7 In coastal zones, the state used the forced labour codes and enforced statutory payment of rent in money to break the labour-rent arrangements employed by old land-owning elites that blocked access to labour for mine and plantation recruitment. ${ }^{8}$ In the cotton-growing areas, each concessionary company was given exclusive right of purchase within a particular zone, usually that surrounding their ginning factories.

Despite this state-regulated regional division of labour there were overlapping and constantly renegotiated competitive demands for labour throughout rural areas. State regulation, pass-laws, the regional division of labour and sector wide cooperation were not sufficient to eliminate competition for labour and to ensure a co-ordinated labour policy. Plantations tried to protect their labour reserves from the incursions of small-holder cashcropping. Sena Sugar Estates, for example, introduced forced cropping of cotton by women in its reserve areas in a negotiated attempt to ward off its introduction for men. WENELA, the Chamber of Mines recruitment agency, had its agents in local recruitment offices provide information on political conditions and potential competition for labour. ${ }^{69}$ Traffic in Mozambican workers to farms in Natal thrived even when it was prohibited by Portuguese and South African governments in the interests of the mine labour convention.

Reconciling competitive demands for labour was one of the principal tasks of district administrators, a recurrent theme of official correspondence in colonial archives. In the then single province of Cabo Delgado/Niassa in 1954, the governor attempted to resolve labour conflicts between the sisal growers and Sagal, the cotton company, by authorising the growers to collaborate in the capture of those individuals who did not cultivate cotton fields of a proper size. ${ }^{-1}$

Settler farmers felt themselves disadvantaged in competition for labour with stronger mining and plantation capital and turned to the local administration to recruit short-term seasonal labour at times of peak labour demand. Both administrators and regulos were known to take gifts and bribes to fulfil requests without sticking closely to regulations that limited, for example, how many months of forced labour a man could be obliged to do during a year. In return for a small gift (saguate) regulos in the lower Limpopo Valley would organise a labour round-up. ${ }^{2}$ Women and children provided most of this seasonal labour for settler farms since men were often migrant workers. Local workers 
were preferred for short-term seasonal work since lodging did not have to be provided.

\subsection{The interdependence of markets: forced and free, labour and commodity}

One of the most tragic misconceptions in socialist Mozambique was that forced labour had been an alternative to the development of markets. ${ }^{13}$ In fact coercion operated through markets, not against them; it integrated markets rather than segmenting or fragmenting them. It linked forced labour with free labour, and peasant cash-cropping with wage-labour.

Forced labour held down wages in general for manual labour because voluntary contract work satisfied the obligation to work under forced labour legislation. Over their working-lives, and sometimes even within an agricultural year, the same people did both shibalo and voluntary labour under contract. Within the same work-place, the same kinds of manual labour were done by both contract and forced workers. They were housed under similar dormitory conditions and subject to the same forms of discipline. Both groups were paid in the same way; wages were discounted for the cost of food and paid by the local administrator only when they returned to their home area. Newitt notes that Sena Sugar used contract labour, but returned periodically to recruitment of shibalo workers in times of labour shortage, as during World War II. ${ }^{-4}$ A 1946 labour census for Lugela, a Zambezia district with tea and sisal plantations and forced cotton-cropping, showed 11,688 men to be productive workers. ${ }^{45}$ Of these 6,112 were recruited for shibalo, 4663 as voluntary workers on plantations and 127 for administration and public works. In these conditions, the minimum wage set by the state for forced labour for a particular region exerted a strong downwards pressure on the prevailing wage for manual labour.

In southern Mozambique voluntary contract work on the mines or migration to the city were alternatives to shibalo. Contracts were not necessarily freely signed; a former WENELA recruiter explained how administrators helped out when recruitment was low, setting up road-blocks where tax-defaulters were snared and offered the choice between penal labour and a WENELA contract ${ }^{46}$. Settler farmers relied longer and more extensively on shibalo than did the plantations, ${ }^{-1}$ but also hired voluntary workers for permanent skilled jobs and for some short-term casual work. Settlers in the Baixo-Limpopo found recruitment links with local families more reliable than shibalo; the settler provided food - maize meal, beans, dried fish, salt sugar and bread - the cost of which was taken out of the wage. 
Similarly forced cash-cropping, particularly of cotton, extended commodity production, but neither created nor entirely displaced free crop marketing. As with shibalo, it was possible to be dispensed from forced cropping by obtaining recognition as a specialised commercial producer of other corps. Besides cotton and rice, forced crops, there was a broad and changing range of produce marketed by the peasantry: livestock, oil crops sesame, peanuts, copra, mafurra , and new cash-crops introduced by local traders - kapok, sunflower, and particularly cashew. The development of plantations created a demand for cheap staple foods, principally maize and dried cassava, that was not satisfied by settler farms. ${ }^{49}$ The colonial state extensively promoted production of cashew and cassava in cotton-growing areas in the $1950 \mathrm{~s}$. ${ }^{0}$ Both were considered to be complementary to cotton in terms of seasonal labour demand. In 1955, textile-crops, mainly cotton, made up $46 \%$ of the value of marketed peasant production in northern Mozambique, but $41 \%$ came from

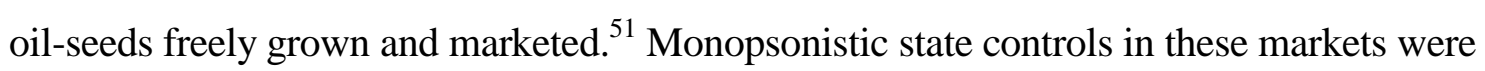
more difficult to maintain than for cotton, but the underlying threat of cash-cropping and shibalo held down prices for peasant-marketed produce. Even cotton itself was after 1946 grown by some on a voluntary basis, with improved state provisioning of incentives, extension, transport and storage, ${ }^{6}$ while others, particularly women in the more marginal cotton areas, grew cotton under the continuing blows of overseers.

Forced labour forged interdependence in labour and agricultural commodity markets and thus between wage labour and petty commodity production. Particularly in central and southern Mozambique, it became almost impossible over time to distinguish sharply between worker and peasant households. Under the forced labour statues, specialised commercial production could also be adjudged by the local administration to satisfy the obligation to work. Although all able-bodied men were by law subject to forced labour, as they grew older, and became senior figures in their own lineages, they were increasingly unlikely to be recruited for shibalo. Many of these marketed substantial crop and livestock surpluses. Further, forced cropping was extended to women even in the labour reserve areas of the south and centre. In Gaza, Inhambane, Zambezia, Sofala and Tete provinces, for example, women were obliged to grow rice and cotton even when their husbands, sons, brothers, fathers and fathers-in-law were contract plantation workers. After the imposition of forced cotton cropping in the northern provinces, labour contracting was reduced but shibalo was still used as a sanction. In 1951, the provincial government of Niassa declared that any male who failed to produce $400 \mathrm{~kg}$. of cotton would be sent to work on tea planta- 
tions, and in 1959, the governor of Nampula required agricultores de algodão to sell a minimum of 750 escudos worth of cotton to retain their exemption from contract labour. ${ }^{53}$

There were two major dimensions of variation in the patterns of market integration under the forced labour regime: region and gender. Although there was increased capitalist farming in the north after the abolition of forced labour, the extent of dependence on wagelabour in rural livelihoods was less than in the rest of the country. There were also intraprovincial or even intra-district differences across all regions between areas that were labour reserves and those that were centres of peasant cash-cropping. These regional differences are still important today, as is implicit in the exchange between and Cramer and Pontara.

The fact that male/female ratios remain an indicator of migration today reflects the second dimension of variation in patterns of market integration and underlying forms of exploitation - gender. Men more often than women confronted capital directly, either as wage-workers or sellers of commodities. Rural labour codes specified that men, not women, would be recruited as migrant labourers. Women's mobility was more sharply constrained by the pass system, and women were required to bear responsibility for food production. In cotton growing areas, men's cotton plots were twice as large as those of women, and men were considered to be the principal market agent in the household, even though women did much of the weeding and harvesting work on all plots. Only when men were physically absent, as in the irrigated rice-schemes of Gaza and Zambezia, were women recognised under the forced labour system as being their own market agents.

There was then great variation and complexity in the functioning of forced labour, but there was also a general structural pattern - accumulation of capital - based on the ways coercion linked wage-labour, cash-cropping and non-marketed production. Wage-labour relations were not uniformly imposed, but for all rural people the colonial period revolutionised rural livelihoods to make wage-labour an alternative. Returning again to the contrast between Gaza and Nampula, Figure 1 does not show only difference in class structure between the two provinces. It also indicates that there is some migration out of rural Nampula and that it differs across age-groups, indicating that migrants tend to return as they grow older to an agricultural base. This is the process of proletarianisation - not to make everyone a wage-worker (both the unemployed and the many women and children who do unpaid work know that to be untrue even in advanced capitalist economies ) but the construction of a world where people buy and sell labour-power. Though history cannot 
be reduced to the logic of capital, capital, despite competition and imperfect control over the state, did have a logic in colonial Mozambique. What then was the impact of the opposing logic of resistance?

\section{RESISTING SHIBALO AND FORCED CROPPING}

There are two principal Marxist criticisms of the literature of resistance (including Scott's 'hidden transcripts' and 'weapons of the weak'): first, that it is populist, failing to see differentiation in peasant response; second, that it does not distinguish between protest that challenges the system and that which allows people to just get by within it. Insurrection is the same as foot-shuffling; singing about suffering is the same as doing something about it. These objections are well taken if the question that we are trying to understand is how organised political protest and revolutionary emancipatory change have developed. The resistance literature powerfully documents, however, that class struggle is reflected in a very broad range of practices of resistance. The forms they take are always shaped by the struggles of oppressors as well as those of the oppressed, and they may turn the exploited into exploiters. Resistance to forced cropping and shibalo in Mozambique, grounded in peasants' attempts to defend their livelihoods, crystallised confrontation with the institutions of the colonial state, but they also drew people more firmly into capitalist relations of production.

There is a growing corpus of historical work on resistance to shibalo and to forced cropping of cotton. ${ }^{66}$ The concept of livelihoods helps us to recognise that what we find in these histories is, despite the polemical power of Cooper's phrase, something much more complex, concrete and varied than people fighting not to become a class. Men and women struggled in different ways in different parts of the country and in different periods to defend and improve their livelihoods. Only rarely do we hear them thinking of themselves in terms as abstract as class; their aspirations and concerns were much more concrete.

The central theme of this literature on resistance to forced labour in Mozambique is not confrontation with capital but evasion. Evidence of collective action by plantation workers B strikes and work-stoppages - has been difficult to find for the period of forced labour. ${ }^{[7}$ Between 1930 and 1960 Sena Sugar Estate records show only one collective demand for higher wages, by river-steamer crews. ${ }^{8}$ Vail and White report, however, that in 1961, just before forced labour was legally abolished a group of workers demonstrated for a pay increase at a tea plantation in Zambezia (Police fired on them and killed fifteen). ${ }^{6}$ 
Similarly, Isaacman, who has with Mozambican colleagues done extensive research on resistance to forced cotton cultivation, found that producers rarely openly refused to plant cotton. ${ }^{60}$ Most cases of boycott took place when cotton was introduced in a particular area. The most militant of these was at Buzi in 1947. Several thousand women, many of whom were the wives or mothers of workers on nearby cane plantations, organised a strike to refuse (unsuccessfully) to accept cotton seed. Both sides in the strike saw the issue to be related to work in the cane-fields. Company officials claimed that the women were being manipulated by their husbands, while women argued that had no time to grow cotton with men working on the plantations.

The most notable protest of cotton growers was presented by a nationalist group, the Makonde National Union, at a meeting with the administrator of Mueda district. ${ }^{\text {They }}$ were demanding the end of forced labour, the right to recruit new members to their cotton marketing association, the opening of more shops and the free marketing of goats, chicken and eggs at acceptable prices. The spokespersons were arrested, the crowd erupted in protest, the administrator gave the order to open fire and hundreds were killed.

There is of course still much research to do on histories of resistance and protest, especially outside archives. Nonetheless, in a world where even basic political rights of assembly and franchise were denied to the colonised subject, where corporal punishment, detention and deportation were so routinely used, and where demonstrations were suppressed by force of arms, it is not surprising that evasion should have been a common pattern of everyday resistance to forced labour.

Evasion did not constitute escape. These struggles to defend livelihoods did not reconstitute a pre-capitalist or pre-colonial world, and certainly not a space outside the world of commodities. ${ }^{62}$ When women in Buzi refused cotton seed, they borrowed the language of strikes from their cane-cutting husbands. When peasants in Mueda demanded an end to forced cropping, they also asked for higher prices for their chickens. Ranger recognised that resistance is not the recovery of the past or even the freezing of the present; he saw 'self peasantisation' in Makoni as something new, though something which took place in defiance of the economic future envisaged by the colonial regime for the district. ${ }^{6}$ Nonetheless his conclusion that constructing alternatives to wage-labour constituted 'peasantisation' and gave rise to a distinctive 'peasant consciousness' is less convincing, for it reduces a complex whole to the appearance of moments within it. Experiences of peasantisation, depeasantisation and repeasantisation have occurred and recurred in greater or lesser 
density in colonial Mozambique, as in Zimbabwe. The linkages between forced and free labour, and between labour and commodity markets meant, however, that each experience of successful peasant production took place within a developing structure of capitalist class relations.

Resistance to forced cropping and forced labour was thus formed by class struggle; each act of resistance elicited a response, not necessarily coherent or efficient, from capital and the state. Evasion rarely allowed more than transient withdrawal from capitalist relations of production. This does not mean that the struggles of rural people were without consequence or that they had no political impact. To the contrary, if we survey the catalogue of resistance that historians have assembled, we can see that resistance to forced labour, like forced labour itself, propelled proletarianisation in a number of ways.

\section{Resistance operated through spaces created by competition among different capitalist interests that allowed workers to abandon one employer for another and even to flee across borders - in search of another paid job.}

One way to resist shibalo was absenteeism, particularly effective in times of labour shortage or if workers came from nearby areas. In the 1950s, the absenteeism rates on sisal plantations in Nampula were around 60 percent and between 45 to 55 percent at the Marromeu sugar estate in Sofala. 64 Workers on tea estates, both contract and shibalo, fled from harsh employers - to other plantations. Tea planters in Zambezia stole each other's workers during the World War II years of labour shortage. If caught, however, fugitive workers were subject to beatings and penal labour. The administrator of Mopeia, the recruitment area for the Marromeu plantations, resolved the absenteeism problem by increased use of corporal punishment. ${ }^{65}$ The political and economic hegemony of big plantation capital in the Zambezi valley underlies Vail and White's conclusion that in the equating of cheap labour with forced labour remained partly valid until 1974.66

A more effective way for men to resist shibalo was to find a better job first, whether within Mozambique or elsewhere in the region. Penvenne has traced how the working class of Maputo grew both through shibalo impressment (dockers and rubbishmen) and evasion of it. ${ }^{67}$ Permanent work on settler farms was better than being a seasonally recruited shibalo worker. In central Mozambique, signing a contract with the plantations was a better option than impressment. The expansion of mining at Moatize gave workers in Tete an alternative to plantation-labour. 68 
Better wages in neighbouring countries made transnational migration the preferred form of resistance to shibalo for young men in labour reserve areas and even for some in cotton-growing areas. In defending themselves against labour monopsony and forced recruitment, men particularly, younger men, sought alternative kinds of work, migrating across southern and eastern Africa, sometimes following older traditions of tramping, or even perhaps using the pre-colonial cohort organisation that was employed by warlords. 69

In central Mozambique, some signed contracts with the RNLB (Rhodesian Native Labour Board). Although those caught travelling without a pass were impressed for penal labour many preferred to cross clandestinely for work on mines and farms in Rhodesia. Some managed to move stepwise on to South Africa, thus subverting the regional labour divide. ${ }^{0}$ The undocumented had to avoid normal routes, border patrols and ferry crossings, for if they were picked up the were channelled directly on to the RNLB for assignment to

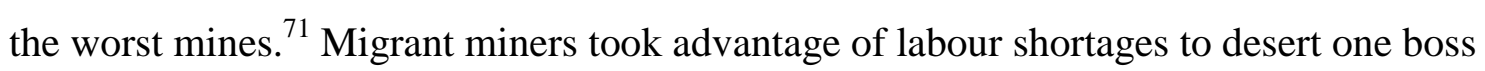
for another, and passed on information about bad work conditions on particular mines. Personal names, maize varieties, house-decoration, the language of work ${ }^{2}$ and evangelical religious movements reflect these labour histories of resistance through border-crossing.

In southern Mozambique, Harris argued, the threat of shibalo underlay the apparently voluntary massive signing up of young men for work on the South African mines. In life-histories recorded in southern Mozambique, ${ }_{4}$ former migrant workers stressed that they avoided shibalo on settler farms by migrating, officially under contract or clandestinely. A former miner from Inhambane lived on the property of a big landowner and thought he would be safe from shibalo. But the landowner charged him 40 escudos a year for the use of a rice plot and then left him no time to work it, so he ran away to the mines. ${ }^{\text {t }}$ There was also great deal of undocumented migration in the South; in the 1950s South Africa and the colonial government struggled to control the movement of Mozambican agricultural workers, men and women, to Natal, where farmers breached labour accords to hire them.

Labour migration across borders to Tanzania, Kenya, Malawi or Zambia was also a way for men to avoid forced cropping in the North. ${ }^{\text {In }}$ Ine mid 1950s, 27,000 Mozambican Makondes were living in Tanganyika out of a population of around 100,000; there were also about 96,500 Makhuas and about 127,000 Ajauas, many of whom were Mozambican migrants.

Evasion through migration was more difficult for women than for men. Pass laws 
were more strict for women; movement also required the permission of a male relative. ${ }^{6}$ In Mozambique, just as Bozzoli 180 pointed out for South Africa, male elders collaborated with colonial authorities to keep women at home. It was easier for women to evade this control in southern Mozambique where the growth of an urban settler community in the 1950s created a demand for women as domestic workers.

There are instances recorded of entire communities emigrating to avoid forced cotton-cropping in both southern and northern Mozambique. In 1939-40, administrators along the border with Swaziland and South Africa and in Manjacaze said people burned their huts and crossed the border rather than cultivate cotton. 82 Led by their regulos, communities fled across borders to Malawi, Zambia and Tanzania to avoid forced cottoncropping. 3 Flight to these neighbouring regions constituted of course, neither withdrawal from colonial domination nor the market. They were met by another colonial administration, restricted access to land and rural poverty.

Since conditions of shibalo recruitment and forced cropping varied by district, communities also moved within Mozambique in times of heightened shibalo recruitment, and under the pressures of forced cropping. ${ }^{84}$ In Niassa, some actually managed to withdraw to the mountains and evade Portuguese control. The story of the rebel community that under the leadership of its chief Namcaoma (whose name means rebel) fled to the top of Mount Mutuene in Cuamba and thus avoided labour obligations and taxes, has assumed the proportions of myth in Mozambican national imagination. The rebels are said to have lived by eating bananas and herding goats, to have beat off repeated Portuguese attacks and to have survived nearly to the end of the colonial period. ${ }^{85}$ Nonetheless, such successful flights were few and generally transient, not constituting a definitive withdrawal from the market and colonial domination.

Resistance to shibalo through flight was not therefore an escape from proletarianisation, but a way of finding a better paid job, or any job. The routinisation of occasional wage-labour in the organisation of rural livelihoods meant that any contraction of wageemployment or decline in commodity prices brought deepening poverty not release. By the 1930s young men were crossing borders in search of employment even when forced labour was not in great use. Newitt observes:

\footnotetext{
At first sight it may seem paradoxical that this great increase in emigration occurred during a decade when forced labour in Mozambique showed a marked decline. However, both the increase in emigration and the abandonment of forced labour has to be seen against a background of the great depression and the collapse of commodity prices. Wages were forced steadily down and the freedom
} 
to contact one's labour voluntarily was a freedom to be exercised in a world of shrinking economic opportunities.

Cotton producers sabotaged their own production so that their areas would be reclassified - making their labour appropriate for another form of exploitation or commoditisation.

The successful way to evade forced cropping was not to flee but to show through poor yields that one's land was not suitable for cotton. Companies required a certain volume of production to make ginning and marketing profitable in a particular area; one of the tasks of the JEAC was to decide which areas were agronomically suitable. In some areas, therefore, peasants worked at lowering cotton yields, by, for example, parboiling cotton seeds before planting. ${ }^{37}$ They refused to tear up and burn old plants, willingly compromising future yields. ${ }^{8.8}$ In protest against carrying $50 \mathrm{~kg}$. bags of cotton long distances to marketing points, they sometimes risked detention by strewing cotton along the roadside as they went. ${ }^{89}$ Tactics of withdrawal worked best in labour reserve areas or in districts where the administration recognised alternative commercial crops.

There was no strong artisanal weaving tradition in Mozambique as there was in parts of the Sahel ${ }^{20}$ to compete for cotton. Unginned cotton is bulky and thus difficult to transport. Only in some border areas were there occasional possibilities of improving the terms of trade by smuggling cotton for sale in adjoining countries. 11 Thus it was difficult for cotton producers to break the companies' monopsony. Producers could subvert the grading and weighing system, by hiding poor quality cotton in bags of first quality or mixing a wide variety of small hard objects with the cotton. Such deception was, however, grounds for detention and beating. It was also only a marginal defence against the companies' tendency to under weigh and to classify first quality cotton as second. Despite mass detentions, there were also some organised boycotts, with peasants burning their cotton or refusing to sell in protest at low prices. The point about many of these protests, however, is exactly that; they were protests about the level of prices, not attempts to withdraw from the market.

Men, particularly, but not only, resisted forced labour by becoming specialised commodity producers, intensifying labour demands on women and children and/or mobilising extra-familial labour - becoming themselves employers of wage-labour.

Colonial legislation provided an alternative way of avoiding forced labour and 
forced cropping - voluntarily becoming a specialised commercial producer. The issuance of a farmer's card (cartão do agricultor) protected the holder from forced labour. New commercial crops were introduced throughout the colonial period by peasants and migrantworkers themselves, as well as by traders, administrators, and settler farmers. In border districts like Sussundenga, Angonia, and Milange, peasant farmers in Manica, Tete and Zambezia sold maize on both sides of the border. 2

Though neither domestic plantation wages nor income from cotton allowed for the accumulation of an investment fund, remittances permitted some migrants to invest in cattle, wagons, sledges and ploughs in southern Mozambique and Manica. In southern Mozambique, missions were allowed to set up a few Christian communities (on the South African model) where men were not subject to forced labour and which became centres of agricultural innovation and marketing. ${ }^{3}$ Isaacman and Chilundo 24 argue that chiefs were principally those who gained from cotton, but that small number of cotton producers teachers, itinerant merchants, returning migrant labourers, prosperous peasants and highly paid cotton gin workers - employed labourers from a pool of impoverished peasants living in adjacent regions. In 1955, towards the end of the forced labour period, a law was enacted governing the creation of 'native co-operative societies,' on lines similar to the marketing co-operatives of British East Africa. A special cotton fund was set up to promote indigenous cultivators. Though more widely discussed than implemented, and limited to areas where there would not be competition for labour with settler farms, successful cooperatives were set up in northern Cabo Delgado and in some localities of the South such as Zavala and Baixo-Limpopo. ${ }^{95}$ In Mueda in the late 1950s, for example, joining the cotton producers' association (SAAVM) assured exemption from recruitment for the Mpanga sisal estates. ${ }^{6}$ A very small number of Mozambicans were also allowed entry with secondary status in the 1950 s to the Limpopo settlement scheme.

Until the 1960s, an alliance of WENELA, settler farmers and plantation capital successfully lobbied the state to limit these schemes and to restrict the number of recognised black commercial farmers. They opposed the development of any indigenous rural petty bourgeoisie that would hinder their access to cheap labour by increasing competition for seasonal labour while drying up their reserves. The cotton companies feared that small commercial farmers would drop cotton for less labour demanding and better earning cashcrops. Peasants were allowed to purchase up to two hectares of commercial land outside the reserves, but to do so they had to demonstrate financial capacity and to pay for demar- 
cation and survey. ${ }^{28}$ By regulating traders' licenses and export permits, the state limited the development of black commercial farmers. A commission of black agricultores in Manica in 1944, for example, wrote to district administration complaining that white farmers received three times more than they did for their maize.

Those who were able to defend themselves against forced labour by becoming commercial farmers thus employed both forced and wage-labour and were most often themselves skilled or privileged wage-workers. Customary authorities and their close kin were the most significant group of commercial farmers until the 1960s; their position was largely dependent on political privilege. Through control over allocation of land, they had access to better commercial land. They also used forced penal labour in their own fields. In Manjacaze, women cultivated rice for the regulo. ${ }^{\infty}$ Similarly Geffray, ${ }^{\infty}$ describes how the regulos and lineage elders in Nampula monopolised cashew growing when the crop was first introduced, impressing workers to plant, clean and harvest their groves.

\section{Women, particularly but not only, resisted intensification of labour and protected subsistence by adapting a range of manufactured commodities into the everyday or- ganisation of livelihoods - in ways that made producing for the market or selling la- bour-power not an option but a necessity.}

Tension between food crops and the forced crops of rice and cotton was inherent in the forced-cropping system. As a rain-fed crop, with heavy weeding demands, cotton cultivation was particularly onerous, competing with food crops for field clearing, weeding and harvesting. Women, who weeded the 2 hectare plots assigned to them and helped with the larger plots of men in the household, sought ways to minimise the time they put into cotton in order to feed and care for their families. Cotton money was usually held by men, and under any circumstances was not sufficient to buy food for household subsistence. Intercropping was forbidden, but the proximity of cotton and food plots made it difficult for field bosses to assure that peasants were not diverting labour from cotton to food. Especially during weeding season, however, this meant hoeing food plots early in the morning and late to sunset, with peasants themselves extending the working day. Population increase in the colonial period is sometimes attributed to pacification and the improvement of medical services. Each may have had its importance, but in Mozambique this increase was only made possible by women's struggles against the intensification of work in cotton to provide the care and food children needed to survive. The success of this 
struggle was also reflected in the low yields registered for cotton in many areas 102 .

The administration fought peasant resistance to cotton by regrouping fields along roads or tracks (picadas) to facilitate supervision. Existing tenure rights were no longer observed in the choice of these sites. In Lugela, Zambezia, cotton producers explained how the capatazes would perch in trees along the picada to survey many producers at one time and quickly spy out the recalcitrant or absent. ${ }^{103}$ The cotton trucks could pass easily along the picadas to distribute seed and pick up cotton at local marketing points. Peasants from Netia in Nampula described the intensification of work under the picada system:

On the picada we worked from five in the morning until five in the evening, first
in our cotton field and then in the food fields. We worked under the constant su-
pervision of our headmen and régulos, of the cotton agents and their foremen, of
the sipaios and police from the administrative post in Netia. The didn't let us rest,
watching us always to keep us from leaving the picada. Who really controlled
everything on the picadas though was the administrator of Netia and the head of
the cotton company in Namialo. 104

In the 1950s, in areas known to have good growing conditions for cotton, the companies, under administrative pressure, improved extension services in some cotton schemes. The number of producers fell, and there was a gradual increase in the average area per producer and per hectare in the 1950s. ${ }^{105}$ Productivity of both land and of each individual grower remained low, however, troubling for cultivation of a crop that uses so much of both. More land was put under cotton, but rotation and periodic fallowing were abandoned; cotton was grown year after year on the same land. The impasse in forced cotton cropping prompted harsh critique of the system by some of the colonial officials involved in it.

The struggle to protect livelihoods - to defend both subsistence and leisure - did not, however, depend only on women extending the working day or diverting labour from cotton when overseers were absent. They also introduced news ways of working and began to use new manufactured commodities in the kind of initiatives Isaacman and others have called coping. ${ }^{107}$ These changes in livelihoods reflected the divergent local histories of different regions. In migrant labour areas the recurrent absence of younger men cut into labour available for field clearance and preparation. In southern Mozambique (and parts of Manica and Tete), this was partially redressed by the rapid switch to ploughing and intensive cultivation of alluvial soils. Those with ox and ploughs acquired through work on the mines rented out their teams for ploughing or transport or ploughed for kin and friends in return for labour cooperation. Some women took on tasks like ploughing and 
caring for cattle which they had not been previously allowed to do. ${ }^{108}$ Those with few resources cleared plots in light sandy soils, easy to work but also not very productive. In central Mozambique and parts of the north, women compensated for seasonal loss of men's labour by using the same fields over and over, carefully burying vegetal material in mounds that were broken down and rebuilt each year. Remittances from migrant remittances were used to buy food and beer for a work-party, or to pay neighbours, particularly children, to help with tasks of cultivation.

These changes in the organisation of agricultural production entailed systematic dependence on purchased inputs though the kind and quantity varied regionally B metal hoe-blades, ploughs, wagons, sledges, dipping, hybrid seeds. ${ }^{109}$ Patterns of consumption shifted and domestic work changed, as consumer goods acquired through wage-work and marketing became part of everyday life B cloth (capulanas), blankets, tin pails for transport and measure, matches, oil, salt, kerosene, anti-malarials. In the South, mine wages were invested in cisterns, roofing material, and bedsteads, while in central Mozambique returning migrants put glass in the windows of their carefully decorated and solidly built permanent houses. Remittances could be used to purchase food locally in times of shortage or crop-failure, and southern migrants sent bags of maize flour to their families from South Africa. Some new goods and services vastly simplified or reduced women's labour B grain milling, cisterns, oil. They thus served in their defence of the subsistence of their families and the struggle against the intensification of their labour while binding them into the market.

The concept of livelihoods helps us to see how inextricably linked production for use and production for exchange became under forced labour regimes. The cotton capulana that carried the child, the plough that cut through heavy alluvial soils and the tin that transported water made it possible to combine cash-cropping, migrant labour and production of everyday subsistence. Both forced labour and resistance to it enmeshed the everyday routines of rural men and women in the market, making participation in the market not a choice, but a necessity. Demand for new kinds of commodities was rooted in broad changes in the organisation of livelihoods B transforming patterns of farming, residence and household formation, consumption and property.

Gender and generational tensions implicit in developing commodity production redefined the meaning of cooperation and sharing - making wage-labour both a mode of 


\section{resistance and a mechanism of security for the impoverished.}

Some forms of resistance to forced labour and cropping B particularly the tendency of men to obtain recognition as 'agricultores' by mobilising the labour of junior men and women to increase their cash-cropping B exacerbated tensions of gender and generation (well highlighted by theorists of the 'lineage mode of production') 10 . Over time these led to changes in the organisation of residence, property and relationship to the market. In migrant labour reserves, labour demands fell particularly hard on young women, who, in areas of virilocal residence were newcomers to the household. They were beginning to bear children and their bridewealth had not always been paid. Conflicts with in-laws led to break-up of some of these marriages and the emergence of women-headed households particularly if an absent husband was not remitting regularly. The following song from Inhambane, one of many on the same theme, captures this tension.

Yes, yes, oh! mother, I weep for my husband (refrain) I weep, I suffer in this house, I weep for my husband. My mother, I don't even have a chicken in my home Now my mother, my little children are ill; I am alone Now my mother, I don't get any sleep in this house Now mother, my little children are ill; his relatives have deserted/don't help me Now I weep for the baby who died in my hands Now mother I don't even have money to consult the diviner I have performed my duties as daughter-in-law but my mother-in-law has thrown me out of her home. Mother, I weep. 111

Generational tensions also emerged within households in the cotton growing areas of central and northern Mozambique where descent is matrilineal and uxorilocal residence was the norm. Here men were expected to live with their wives' parents and/or do brideservice working in the cotton fields of their wives' parents. ${ }^{-1}$ Geffray records that headmen expanded their own cotton production in Erati in Nampula by mobilising the labour of young men, who were thus forced to divert effort from their own fields. ${ }^{1.3}$ He suggests that what is sometimes interpreted as resistance to cotton as a crop was actually the resistance of young men to exploitation by lineage elders. ${ }^{14}$ There was also friction between women and their mothers over the allocation of work, since women had no control over the granary until their own daughters married. When cashew was introduced on a large scale in Nampula, headmen at first prohibited planting by subordinate men of the lineage and recruited labour for large-scale planting. Forced individual planting of cashew seed, which was distributed with cotton seed, helped younger men to subvert the labour claims of elders. 
Traders and cotton-companies had no particular reason for observing lineage hierarchies in buying peasant produce. By 1961, not only most headmen, in Erati, but also most men of the lineage owned cashew trees, which they treated as their own individual property.

These tensions of gender and generation exacerbated by forced cropping and shibalo sometimes resulted in rupture of households. In the north, forced resettlement along picadas loosened matrilineal rules of land access and uxorilocal household formation; some couples moved separately to the picada. Young men migrated as an alternative to bride-service. In the South, where almost all men migrated, some women left their in-laws, to return to their own families, to set up their own households or to move to urban areas. These smaller households, often with less social support, were those most vulnerable to illness and crop-failure. From their ranks came those who did casual wage-labour, on piece or target rate, or for food.

In song, sculpture, dance and acerbic jest, peasants and workers both expressed their suffering under the forced labour system and ridiculed their oppressors, challenging the terms under which they worked and sold the products of their labour but also normalising a world of labour migration and commodity exchange.

The mother-in-law plaint registered above is part of a rich corpus of songs of protest gathered by historians in rural areas of Mozambique. ${ }^{105}$ Two themes dominate the songs - suffering and ridicule. 'We are being tortured by cotton, We are fed up from suffering under the Portuguese. ${ }^{\square 6}$ For an overseer, "This monkey is stopping here, why? He is stopping here because he has nothing else to do.

Isaacman argues that a culture of opposition was constructed through such songs: 'Defiance of the dominant culture was an act of empowerment and often heightened peasant opposition, which in turn influenced their consciousness. ${ }^{118}$ The songs complain of the conditions under which people worked - of the measly prices paid for cotton or the cruelty and stupidity of overseers, or the pain of losing one's husband to the mines, but they also normalise a world of cash-cropping and labour migration. A woman from Cabo Delgado told Isaacman that chiefs, overseers and police who understood their songs often disregarded their mocking tone and discounted their subversive potential, as long as the women kept working while they were singing. ${ }^{10}$ In themselves, songs, dance, sculpture and jest could provide only very transient moments of empowerment.

What empowered these local cultures of opposition, turning the normal into the 
contested, was their linkage to broader nationalist ideologies that crossed classes, regions, gender and age differences and kinds of work. These linkages emerged from histories of labour migration that exchanged experiences and made new connections in the context of emerging nationalist movements within southern and eastern Africa. They also emerged from the processes of rural differentiation and privileges of class that allowed the sons of chiefs and specialised commercial producers to pursue their studies and to engage with revolutionary intellectuals outside the boundaries of Mozambique. They were forged, that is, from the broader processes of proletarianisation that cross-cut and united local struggles.

\section{CONCLUSIONS}

When forced labour ended in 1961 in Mozambique, the number of permanent wage-workers was very small and there was certainly no landless proletariat. This was an economy based on coercion; both wages and prices paid to peasant were very low, and did not provide most rural families with an alternative to producing their own food. Yet we cannot possibly understand the dilemmas that rural Mozambicans confront today without understanding forced labour as part of an irreversible historical process of proletarianisation. The dialectic between exploitation and resistance in shibalo and forced cropping did not operate in opposition to labour and commodity markets in colonial Mozambique, but within them. In doing so, it revolutionised rural livelihoods, turning everyday production of subsistence dependent on participation in the market.

Wage-labour was not an invariant or irreversible element in this process, particularly since rural people kept access to land. Men who had been wage-labourers often moved into commercial production later in their lives. Some areas that had been labourreserves became in the 1960s strong centres of cash-cropping. Even with the sharp decline in peasant cotton marketing after 1970, peasant production for food markets and their own subsistence remained central for reproduction of capitalist production in both country and city and in all provinces. But dependence was two-sided. A large, though regionally variable, proportion of rural households depended on income from off-farm employment for the reproduction of their subsistence production. This necessary income came in part from remittances from migrant workers: miners, farm-workers, urban workers and the selfemployed. It also came from local off-farm employment, including casual labour for large capitalist farms and small-scale specialised commercial peasant-farmers.

It is true that much Marxist literature on Africa has presented an incomplete view 
of how livelihoods became so inextricably linked to the market in the colonial period. Images of English enclosures and rural landlessness in Latin America have shaped our tendency to understand separation from the means of production as inevitably and irreversibly the loss of land. We have thus had difficulty understanding why producers were separated from their means of production in parts of Africa where customary tenure regimes maintained access to land (though not necessarily equitable distribution of it). The development of wage-labour relations in Mozambique depended not on alienation of land but on changes in the production of everyday livelihoods that intertwined production for use and for exchange. Both forced labour and resistance to it linked labour and commodity markets, making movement in and out of wage-labour part of everyday rural life.

The history of forced labour in Mozambique provides support for the classical Marxist critique of those who conflate agency with subjective intention (or worse maximisation of individual utility) and oppose structure to agency. Peasants in Mozambique struggled neither to become a proletariat nor not to become one. Their struggles expressed their various identities, aspirations, resources and possibilities, but the outcomes of what they did both reflected and shaped structural consequences beyond their own local visions. Those fleeing from shibalo on settler farms to the South African mines brought themselves more firmly into wage-labour relations and collectively influenced the terms of wagelabour in regional labour markets. Mother-in-laws in Gaza who sought to defend the subsistence of their households against the demands of forced rice or cotton cropping by pressuring their daughters-in-law to work harder did not intend to create women-headed households dependent on casual wage-labour. Those who signed up for credit and extension schemes for cotton did not intend to become petty capitalists, but they could not finish their weeding without wage-labour. Capitalist enterprises and state-agencies coercively recruiting contract workers in Mozambique were only trying to assure a cheap, rural-based labour force, not to create a mobile migrant regional labour-market, and certainly not a politically militant inter-class nationalist opposition.

The concept of multiple livelihoods allows us to look at aspects of the forced labour system which the first round of pioneering work on proletariansiation in southern Africa did not adequately explore. If, however, we allow 'thick description' of rural livelihoods to displace rather than complement class analysis, we compromise our understanding of the dynamics of both forced labour and proletarianisation, and of their implications for the options faced by rural people in Mozambique today. The historical processes of 
commoditisation, shaped by forced labour, made labour everywhere in Mozambique a potentially saleable commodity. Though wage labour is neither inevitable nor irreversible, this revolutionary process, proletarianisation in its broader sense, is irreversible. ${ }^{20}$ Crises of accumulation and restructuring of capital in southern Africa have led to unemployment in formal wage-sectors, yet young people continue to flow out of rural areas looking for jobs. It is ironic, perhaps tragic, that the concept of proletarianisation, which helps us to understand this process, should be today dismissed in discussions of rural livelihoods in southern Africa.

Worse still is to reduce the documentation of livelihoods to description of how individuals strategically manage their resources, abstracting from cross-cutting structural relations of class and power, and reducing agency to individual choice. For then it becomes very difficult to see how forms of collective action can and have changed both options and the ways they are envisaged. Dominant theoretical discourse now polarises macro/ micro and structure/agency and then tells us that the first terms are illusory abstractions, that social patterns can only be aggregation of the exercise of individual agency (choice) at the micro-level. To the contrary, structure is contingent and contradictory; agency is structured. By focussing on forced labour, it could be argued, I have loaded the argument; most find game-playing to be a distasteful metaphor for shibalo and forced cropping. I have done so, however, precisely because rural life in southern Africa today cannot be understood by an analytical approach that treats history only as context for individual choice. The colonial past, constructed through class struggle by workers and peasants as well as capitalists and colonial bureaucrats, lives on in the contradictory realities of proletarianisation.

'Men make their own history, but they do not make it as they please; they do not make it under self-selected circumstances, but under circumstances existing already, given and transmitted from the past,' Karl Marx, The Eighteenth Burlier of Louis Bonaparte. 
Proportion of peasant population in total population 15 and over per province Mozambique Census 1997 POPULACAO OCUPADA DE 15 ANOS E MAIS POR RAMO DE ACTIVIDADE SEGUNDO AREA DE RESIDENCIA, SEXO E OCUPACAO PRINCIPAL. IIRGPH, 1997.

\begin{tabular}{|c|c|c|c|c|c|c|c|c|c|c|c|}
\hline & Niassa & $\begin{array}{c}\text { Cabo } \\
\text { Delgado }\end{array}$ & Nampula & Zambezia & Tete & Manica & Sofala & $\begin{array}{c}\text { Inhamban } \\
\mathrm{e}\end{array}$ & Gaza & $\begin{array}{l}\text { Maputo } \\
\text { prov. }\end{array}$ & $\begin{array}{c}\text { Maputo } \\
\text { City }\end{array}$ \\
\hline $\begin{array}{l}\text { Men } \\
\text { peasants }\end{array}$ & 106,815 & 241,147 & 488,316 & 432,293 & 156,764 & 89,781 & 107,597 & 124,709 & 91,904 & 32,171 & 3,992 \\
\hline Total & 134,513 & 286,461 & 643,273 & 547,111 & 193,174 & 149,848 & 225,823 & 186,622 & 143,098 & 137,878 & 183,344 \\
\hline 1997 & $79.41 \%$ & $84.18 \%$ & $75.91 \%$ & $79.01 \%$ & $81.15 \%$ & $59.91 \%$ & $47.65 \%$ & $66.82 \%$ & $64.22 \%$ & $23.33 \%$ & $2.18 \%$ \\
\hline $\begin{array}{l}\text { Women } \\
\text { peasants }\end{array}$ & 120,108 & 295,287 & 589,994 & 584,796 & 199,776 & 132,254 & 195,081 & 268,495 & 260,297 & 94,286 & 18,153 \\
\hline Total & 125,968 & 302,882 & 608,336 & 600,740 & 209,391 & 146,491 & 217,015 & 293,117 & 276,438 & 136,282 & 117,615 \\
\hline Percentage & $95.35 \%$ & $97.49 \%$ & $96.98 \%$ & $97.35 \%$ & $95.41 \%$ & $90.28 \%$ & $89.89 \%$ & $91.60 \%$ & $94.16 \%$ & $69.18 \%$ & $15.43 \%$ \\
\hline
\end{tabular}




\section{ENDNOTES}

1. According to a WENELA presentation at the Afro-Luso-Brasileiro Social Science Conference, Eduardo Mondlane University, Maputo, September 1998, WENELA/TEBA plans to transform itself from a labour contractor to a service agency paid by miners themselves for forwarding their baggage, arranging insurance and delivering remittances.

2. C. Cramer and N. Pontara, 'Rural poverty and poverty alleviation in Mozambique: what's missing from the debate?,' The Journal of Modern African Studies (36, 1, 1999), pp. 101-138, and 'Reply to Pitcher,' The Journal of Modern African Studies (37. 4. 1999), pp. 711-722.

3. M. Anne Pitcher, 'What's missing from "What's missing"? A reply to C. Cramer and N. Pontara, "Rural poverty and poverty alleviation in Mozambique: what's missing from the debate?",' The Journal of Modern African Studies (37, 4, 1999), pp. 697-709.

4. Pitcher, 'What's Missing,' p.706.

${ }^{5}$.This was the subtitle of an excellent collection of papers by Émile le Bris, P.-Ph. Rey and Michel Samuel, Capitalisme négrier, la marche des paysans vers le prolétariat (Paris, Maspero, 1976), dealing with labour migration and proletarianisation in West Africa.

${ }^{6}$.Terence, Ranger, Peasant Consciousness and Guerilla War in Zimbabwe, A Comparative Study (London: James Currey and Berkeley and Los Angeles, University of California Press 1985), p. 29 shows selfpeasantisation in the aftermath of conquest. See also E. Schmidt, Peasants, Traders, and Wives: Shona Women in the History of Zimbabwe, 1870-1939 (Portsmouth, N.H., Heinemann. 1992); Angela, P. Cheater, Idioms of Accumulation: Rural Development and Class Formation among Freeholders in Zimbabwe, (Gweru, Mambo Press 1984).

7. Henrietta L. Moore and Megan Vaughan, Cutting Down Trees: Gender, Nutrition and Agricultural Change in the Northern Province of Zambia, 1890-1990 (London, James Currey 1994).

${ }^{8}$.William Beinart and Colin Bundy, Hidden Struggles in Rural South Africa (London, James Currey, Berkeley and Los Angeles, University of California Press, and Johannesburg, Ravan Press 1987).

9 . Ranger, Peasant Consciousness.

${ }_{10}$. P.-Ph. Rey, Colonialism, néo-colonialisme et transition au caitalisme (Paris, Maspero 1971).

${ }^{11}$. See inter alia Ranger, Peasant Consciousness; Charles Van Onselen, Chibaro, African Mine Labour in Southern Rhodesia, 1900-1933 (London, Pluto Press, 1976); Allen F., Isaacman, Cotton is The Mother of Poverty: Peasants, Work and Rural Struggle in Colonial Mozambique, 1938-1961 (Portsmouth, N.H., Heinemann and London, James Currey 1996).

${ }^{12}$. Frederick Cooper, 'Urban Space, Industrial Time and Wage Labor in Africa,' in F. Cooper, Ed., Struggle for the City: Migrant Labor, Capital and the Struggle for Urban Africa (Beverly Hills, Ca., Sage Series Vol. 8,1983), pp. 7-50.

13. Isaacman, Cotton is the Mother, p. 240.

${ }^{14}$. Herbert Aptheker, American Negro Slave Revolts: Nat Turner, Denmark Vesey, Gabriel, and others (New York, International Publishers 1963); E. J. Hobsbawm, Primitive Rebels: Studies in Archaic Forms of Social Movement in the 19th and 20th Centuries (Manchester: Manchester University Press, 1959); Eric Foner, Nat Turner (Prentice-Hall, Englewood Cliffs, N.J. 1971); Eugene Genovese, Roll, Jordan, Roll: The World the Slaves Made (New York, Pantheon Books 1974).

${ }^{15}$. For an extended discussion of the colonisation of social sciences by the methodological individualism of neoclassical economics, (in the work of Amartya Sen as well as Gary Becker) see Ben Fine, 'The Developmental State is Dead - Long Live Social Capital,' Development and Change 30,1, (1999), pp. 1-19, and Ben Fine, Social Capital Versus Social Theory : Political Economy and Social Science at the Turn of the Millennium (London and New York, Routledge 2001).

16. See for example John Farrington, Diana Carney, Caroline Ashley and Cathryn Turton, Sustainable Livelihoods in Practice: Early Applications of Concepts in Rural Areas Natural Resource Perspectives (Number 42, June 1999, ODI), http://www.oneworld.org/odi/nrp/42.html, downloaded 10.3.2001, and various contributions on livelihoods frameworks in Emerging Issues in Rural Development: A Background Paper (London,: ODI, January 2001), http://www.agronor.org/RDbackground.htm, downloaded 10.3.2001. 
17. On the influence of Amartya Sen, Poverty and Famines, An essay on Entitlement and Deprivation, (Oxford, Clarendon Press, 1981), see, for example, Robert Chambers, and Gordon R. Conway, 'Sustainable rural livelihoods: practical concepts for the 21st century,' Institute of Development Studies discussion papers No. 296 (Brighton, GB: University of Sussex Institute of Development Studies, 1992), Frank Ellis Rural livelihoods and diversity in developing countries (Oxford, Oxford University Press, 2000) and the institutionalist approaches that dominate http://www.livelihood.org.

18. Patrick Harries, Work, Culture and Identity: Migrant Laborers in Mozambique and South Africa, $c$. 1860-1910 (Portsmith, NH, Heinemann 1994); Luis A Covane, 'Considerações Sobre o Impacto da Penetração Capitalista no Sul de Moçambique, 1850-1876,' Cadernos de História 7, 2, 1988) pp. 91-106.

19. Vail and White, Capitalism and Colonialism; Edward A. Alpers, "To Seek a Better Life:' The Implications of Migration from Mozambique to Tanganyika for Class Formation and Political Behavior.' Canadian Journal of African Studies 18, 2, (1984), pp. 367-388; Carlos Serra, 1986, Como a penetraçäo estrangeira transformou o modo de produçäo dos camponeses moçambicanos - O exemplo da Zambezi (+/1200/1964, Volume II (Maputo, Universidade Eduardo Mondlane 1986) p. 29; Shubi Ishemo, , 'Forced Labour, Mussoco (Taxation), Famine and Migration in Lower Zambézia, Mozambique, 1870-1914,' in Abebe Zegeye and Shubi Ishemo, Eds., Forced Labour and Migration: Patterns of Movement within Africa (London, Munich, New York, Hans Zell 1989), pp. 109-158.

20. Jeanne Penvenne, African Workers and Colonial Racism, Mozambican Strategies and Struggles in Lourenço Marques, 1877-1962 (Portsmouth, N.H., Heinemann and London, James Currey 1995), p. 105; Newitt, A History, p. 383.

${ }^{21}$. Newitt, A History, p. 409.

22. Carlos Fortuna, O Fio da Meada: O Algodao de Moçambique, Portugal e a Economia-Mundo (1860-1960) (Porto, Ediçöes Afrontamento, 1993), p.180.

${ }^{23}$.Van Onselen Chibaro, Ruth First, Black Gold, the Mozambican Miner, Proletarian and Peasant, (Sussex, the Harvester Press 1983); Marc Wuyts,'Economia Política do Colonialismo em Moçambique',Estudos Moçambicanos (1, 1980), pp. 9-22.

${ }^{24}$.Cf. Joaquim Granger, 'A convençäo,' Boletim da Sociedade de Estudos da Colónia de Moçambique (II, 10, 1933) pp. 1-65.

${ }^{25}$.Fortuna, O Fio da Meada, p. $106 \mathrm{ff}$.

${ }^{26}$. Newitt, A History, p. 409.

27. Newitt, A History, p. 384.

28. The term is used throughout the Southern African region. Variant forms include chibaro and chiballo. This paper uses shibalo, as a phonetic approximation. The derivation is possibly from the Portuguese word for work, trabalho.

29. After 1914, a small wage was also paid for penal labour, Newitt, A History, p. 411.

30. See B. O'Laughlin, 'Class and the Customary: the ambiguous legacy of the Indigenato in Mozambique,' African Affairs $(99,194,2000)$ : 5-42, for an analysis of the relationship between forms of local governance and forced labour.

31 . C. Meillassoux, Femmes, greniers, et capitaux (Paris, Maspero, 1975).

${ }^{32}$. A point observed about Rhodesia by G. Arrighi, Giovanni, 'Labour Supplies in Historical Perspective: A Study of the Proletarianisation of the African

Peasantry in Rhodesia,' in G. Arrighi and J. Saul, Eds., Essays on the Political Economy of Africa (New York, Monthly Review Press 1973), pp. 180-234.

33. A. Rita Ferreira, Rita Ferreira, A., 1967-8, Os Africanos de Lourenço Marques, Lourenço Marques, Memórias do Instituto de Investigaçäo Científica de Moçambique (1967-8) p. 156.

34. This was particularly true in economically marginal districts. Isaacman, Cotton is the Mother, p. 218, quotes the administrator of Mocimboa de Praia who in 1946 noted that the impact of the concessionary company overseer was minimal since he lived $50 \mathrm{~km}$. from the cotton fields, and neither he nor the administrator had any transport.

35. Pitcher, 'From Coercion to Incentives.'

36. Alpheus Manghezi,, 'History and Organisation of Labour Recruitment in Southern Mozambique', draft manuscript (n.d.).

37. CEA research, Alta-Zambézia, 1981.

${ }^{38}$. D. Hedges and A. Rocha, 'A Reestruturação da Sociedade Mocambicana, 1938-1944,' in Aurélio Rocha, et al., História de Moçambique, Vol. III, Moçambique no auge do colonialismo, 1930-1961, (Maputo, Universidade Eduardo Mondlane, Departamento de História, 1993), 112-113. 
39. The regional Wenela manager wrote a directive in 1961 attributing a drop in recruitment in Zavala, Inhambane, to the development of agricultural marketing co-operatives, CEA Archives, W.N.L.A. LTD., Circular D/A No 15a/61, 22 May, 1961.

${ }^{40}$.David Lincoln, 'Plantation Agriculture, Mozambican Workers and Employers Rivalry in Zululand, 1918-1948,' in Alan Jeeves and Jonathan Crush, Eds., White Farms, p. 139.

41. Yussuf Adam and A.M. Gentili, 'O Movimento dos Liguilanilu no planalto de Mueda,' Estudos Moçambicanos $(4,1983)$, p. 46.

${ }^{42}$.Ana João da Silva, 'Diferenciação camponesa e agricultura colonial: o caso do Baixo Limpopo, Distrito de Xai-Xai, 1950-74,' Trabalho de Diploma, Instituto Superior Pedagógico, (Maputo, 1992).

${ }^{43}$. It was thought that the peasantry would withdraw from the market and stop producing surpluses once force was removed. Hence rapid growth could only be achieved through concentration of investment in statefarms and industries and the peasantry could get along without consumer goods.

${ }^{44}$. Newitt, A History, p. $423 \mathrm{ff}$.

${ }^{45}$.CEA (Centro de Estudos Africanos), 'O trabalhador sazonal na transformaçäo duma

economia de plantaçöes', CEA Relatorio 81/4 (Maputo, Eduardo Mondlane University, 1981), p. 20.

46. Manghezi, 'History and Organisation.'

47. Jeanne Penvenne, African Workers p. 7.

48 . da Silva, "Diferenciação camponesa'.

49. Maureen Mackintosh, 'Agricultural Marketing and Socialist Accumulation A Case Study of Maize Marketing in Mozambique', Journal of Peasant Studies 14, 2, 1987), pp. 243-267.

${ }^{50}$.Dried cassava was marketed as food for plantation and urban workers, but cassava was also promoted as a staple alternative to sorghums and millets for household subsistence, particularly after famines in the late 1940s.

${ }^{51}$.Calculated from Estatística Agrícola de Moçambique (Lourenço Marques. 1955).

52 . M. Anne Pitcher, Politics in the Portuguese Empire: the state, industry and cotton, 1926-1974 (Oxford, Clarendon Press 1993), p. 197 and 'From Coercion to Incentives: The Portuguese Colonial Cotton Regime in Angola and Mozambique, 1946-1974,' in A. Isaacman and R. Roberts, eds., Cotton, colonialism, and social history in sub-Saharan Africa, (Portsmouth, N.H, Heinemann and London, James Currey 1995), pp. 119-143.

53. Allen Isaacman and Arlindo Chilundo, 1995, 'Peasants at Work: Forced Cotton Cultivation in Northern Mozambique 1938-1961,' In Allen Isaacman and Richard Roberts, Eds., eds., Cotton, colonialism, and social history in sub-Saharan Africa, Social History of Africa series (Portsmouth, N.H., Heinemann and London, James Currey 1995), p. 167.

54. Whitehead and others looking at gender issues in development in West Africa emphasised that Boserup's notion that capitalist development brought men into the market while relegating women to the sphere of subsistence missed a central element in the process, namely that a good deal of the income earned by men through cash-crop production depended on women's farm labour, see Ann Whitehead, Ann, 'Food Crisis and Gender Conflict in the African Countryside,' in H. Bernstein, et al. (eds), The Food Question, Profits versus People? (London, Earthscan 1991), pp. 54-68.

55. T. O. Ranger, 'The people in African resistance', Journal of Southern African Studies, 4, 1 (1977), pp. 125-146 provides a good summary of the Marxist criticisms of that time and of his response (in a time of flush about socialist revolutions in Africa. Tom Brass, Towards a Comparative Political Economy of Unfree Labour, Case Studies and Debates (London and Portland, Or.: Frank Cass 1999), p. 254 builds a robust Marxist attack in the South Asian context on James C., Scott, Domination and the Arts of Resistance, Hidden Transcripts (New Haven and London, Yale University Press 1990) and Weapons of the Weak: Everyday Forms of Peasant Resistance (New Haven, Yale University Press 1985).

56. See inter alia Corrado Tornimbeni, Labour migration in Central-Southern African and Tete District, Mozambique, 1890-1945, MA dissertation in African Studies, SOAS, London 14.9.99; J. das Neves, Economy, Society and Labour Migration in Central Mozambique, 1930-c. 1965: A Case Study of Manica Province, PhD Thesis, SOAS (1999); University of London; Vail and White, Capitalism and Colonialism; L Vail,. and L. White, 'Forms of Resistance: Songs and Perceptions of Power in Colonial Mozambique,' American Historical Review (88,4, 1983), pp. 883-919; Charles Van Onselen, Chibaro; Jeanne Penvenne, African Workers and Colonial Racism, Mozambican Strategies and Struggles in Lourenço Marques, 1877-1962 (Portsmouth, N.H., Heinemann and London, James Currey.1995); Nelson Saraiva Bravo, A cultura algodoeira na economia do norte de Moçambique, (Lisbon 1963); Isaacman, Cotton is The Mother; Allen Isaacman and Arlindo Chilundo, 'Peasants at Work', pp. 147-179. Evidence is still scattered, however, at very wide intervals over space and time. 
${ }^{57}$.This does not imply a contrast between rural and urban contract workers in levels of militance. Jeanne Penvenne, 'A Luta Continua! Recent Literature on Mozambique, International Journal of African Historical Studies $(18,1,1985)$, pp. 109-138, observes that she could not find confirmation for all the post World War II strikes among dockworkers claimed by some researchers. There may be, however, hidden histories of protest, particularly for the 1960s. Alexandrino José, in his research on protest among port-workers, found that Frelimo's strong condemnation of strikes during the transitional government period and its subsequent vigorous anti-strike policy made if very difficult for him to confirm any evidence of protest. Participants in strikes during the 1960s were likely to have been involved in subsequent protest as well. Alexandrino F. José, A greve dos carregadores da estiva do porto Comercial de Lourenço Marques em Agosto de 1963 no contexto da luta de libertação nacional de Moçambique e alguns problemas na reconstrução da história do operariado moçambicano (Maputo: UEM, dissertação para o grau de licenciatura em história 1987).

${ }^{58}$. Judith Frances Head, State, Capital and Migrant Labour in Zambezia, Mozambique: A Study of the Labour Force of Sena Sugar Estates Limited, PhD thesis, Department of Sociology and Social Administration, University of Durham (1980), p. 331.

59. Vail and White, Capitalism and Colonialism, p. 272.

${ }^{60}$. Isaacman, Cotton is the Mother, p. 217.

61. This account is taken from David Hedges, and Arlindo Chilundo, 'A Contestação da Situação Colonial, 1945-1961, ' in Aurélio Rocha, et al., História de Moçambique, Vol. III, Moçambique no auge do colonialismo, 1930-1961 (Maputo: Universidade Eduardo Mondlane, Departamento de História 1993) pp. 241-242.

62. Van Onselen, Chibaro.

63. Ranger, Peasant Consciousness, p. 29.

${ }^{64}$. Hedges and Chilundo, 'A Contestação,' p. 214.

65. Ibid., p. 214.

${ }^{66}$.Vail and White, Capitalism and Colonialism, p.386.

${ }^{67}$. Jeanne Penvenne, 'Shibalo e Classe Operária: Lourenço Marques 1870-1962,' Estudos Moçambicanos (2, 1981), pp. 9-26.

68. Centro de Estudos Africanos, Angonia Research 1982.

69. Harries, Work, Culture and Identity, Newitt, A History, p. 576.

${ }^{70}$. Van Onselen, Chibaro; Tornimbeni ,Labour Migration; das Neves, Economy, Society and Labour.

${ }^{71}$.Van Onselen, Chibaro. Hence the fact that working for the RNLB was called chibaro.

${ }^{72}$.The term use for rural day-labour, usually on a task basis, is ganho-ganho (from the Portuguese ganhar, to earn); in Malawi, the term is ganyu, an artifact of the border-crossing of rural workers from both sides.

73 . Marvin Harris, Harris,'Labour Emigration among the Mozambican Thonga: Culture and Political Factors,' Africa (29, 1959), pp. 50-66.

74. Jeanne Penvenne, Port Interviews, CEA Archives, and interviews done by Alpheus Manghezi, Salamao Zandamela, Alexandrino Jose and research brigades in CEA archives (CEA Inhambane 1977, CEA port research 1981), Ruth First, Black Gold, the Mozambican Miner, Proletarian and Peasant, (Sussex, Harvester, 1983) and A. José, A Greve dos carregadores.

${ }^{75}$. CEA research Homoine, 1977.

76. Lincoln, 'Plantation Agriculture.'

77 . E. Alpers, 'To Seek a Better Life.'

78 . Adam and Gentili, 'O Movimento,' p. 49.

${ }^{79}$. Rita Ferreira, Os Africanos, p. 156.

${ }^{80}$. B. Bozzoli, Consciousness, Life Strategy, and Migrancy in South Africa, 1900-1983, (Portsmouth, N.H., Heinemann and London, and James Currey 1991).

81. Jeanne Penvenne, African Workers and Colonial Racism, Mozambican Strategies and Struggles in Lourenço Marques, 1877-1962 (Portsmouth, N.H., Heinemann and London, James Currey 1995), p. 152.

${ }^{82}$. Hedges and Rocha, 'A Reestruturação,' p. 111.

83. Isaacman, Cotton is the Mother; Fortuna, O Fio da Meada, p.150.

${ }^{84}$. CEA Research, Lugela 1980 and Isaacman, Cotton is the Mother.

${ }^{85}$.Isaacman, Cotton is the Mother, p. 213. Such flights were also undertaken during the recent war from government areas to Renamo held areas.

${ }^{86}$. Newitt, A History, p. 511.

${ }^{87}$. Isaacman, Cotton is the Mother; Hedges and Chilundo, 'A Contestação.'

${ }^{88}$. Bravo, A cultura algodoeira; Isaacman et al. 1980: 6] 
89. A. Isaacman et al., Isaacman, A. et al., 'A resistência popular a cultura forçada do algodão em Moçambique, 1930-1961,' (CEDIMO Série A, 10, 1980-08-12), p. 6.

90. Richard Roberts, 'The Coercion of Free Market: Cotton, Peasants and the Colonial State in the French

Soudan, 1924-1932', in Isaacman and Roberts, eds., Cotton, colonialism, pp. 231-243.

91 . Isaacman, Cotton is the Mother, p. 220.

92. See Marvin Miracle, Maize in Tropical Africa (Madison, Wisconsin University Press 1966), pp. 154-5.

93. Alpheus Manghezi, 'Ku thekela: Estratégia de Sobrevivência contra a Fome no Sul de Moçambique' Estudos Moçambicanos (4, 1983), pp. 19-40.

${ }^{94}$. Isaacman and Chilundo, 'Peasants at Work,' p. 171.

95 . cf. Yussuf Adam, Cooperativização agrícola e modificação das relações de produção no período colonial em Moçambique, Tese de Licensiatura, Universidade Eduardo Mondlane, Maputo.(1987).

${ }^{96}$. Adam and Gentili, 'O movimento,'p. 46.

${ }^{97}$. K. Hermele, Hermele, Kenneth, Land Struggles and Social Differentiation in Southern Mozambique: A case study of Chokwe, Limpopo, 1950-1987 (Uppsala, Scandinavian Institute of African Studies. 1988). This was an irrigated settlement scheme promoted as the TVA of Mozambique.

98 . John W. Bruce, 'Land Policy and State Farm Divestiture in Mozambique' (Madison, Land Tenure Center, University of Wisconsin 1990), p. 2.

99 . Hedges and Rocha, 'A reestruturação,' p. 107.

100 . D. Hedges and A. Rocha, 'Moçambique durante o Apogeu do colonialismo Português, 1945-1961: a Economia e a Estrutura Social,' in Aurélio Rocha, et al., História de Moçambique, Vol. III, Moçambique no auge do colonialismo, 1930-1961 (Maputo, Universidade Eduardo Mondlane, Departamento de História 1993), p. 149.

101. Christian Geffray, 1985, 'Transformations historiques de l'organisation familiale Ma-Khuwa 1940-1975 (Erati)' (Paris, Rapport 4).

102. Isaacman, Cotton is the Mother, p. 236. The relationship between productivity and resistance was variable, however, across time and between regions. The following data, illustrating shifting but still very low productivity of land and particularly of labour are from Lugela, Zambezia, where where recruitment for cotton and plantations overlapped.

Table 1 Cotton productivity under forced cropping in Lugela

\begin{tabular}{|c|c|c|c|c|c|l|}
\hline Year & N. producers & N. ha. & Total prod. (ton.) & Ha. per producer & Kg. per producer & Kg. per ha. \\
\hline 1944 & 18396 & 3317 & 909 & 0.18 & 49 & 274 \\
\hline 1952 & 8284 & 2345 & 604 & 0.28 & 73 & 258 \\
\hline 1960 & 10999 & 4058 & 1262 & 0.37 & 115 & 311 \\
\hline
\end{tabular}

Source: Centro de Estudos Africanos, Já não batem (Maputo, Eduardo Mondlane University, 1981),

103. CEA research Lugela 1980.

Report 1981/3.

${ }^{104}$. Kurt Habermeier, 'Algodäo: Das Concentraçöes à Produçäo Colectiva,' Estudos Moçambicanos (2 1981), p. 38.

105. Pitcher, 'From Coercion to Incentives,' and Centro de Estudos Africanos (CEA), Cotton Production in Mozambique, a Survey, 1936-1979 (Maputo, Eduardo Mondlane University, 1981) Report 1981/1. See also note 102.

106. Bravo, A cultura algodoeira

107. Isaacman's distinction between coping and resistance rests on intention, whether minimising adverse effects (coping) or struggling over power and resources (resistance). I prefer to avoid characterising intentions, since these are as Isaacman himself notes polyvalent, see A. Isaacman, Cotton is the Mother, p. 192. Struggling to sustain livelihoods can imply both simply getting along or confrontation. The implicit characterisation of women as copers and men as resisters is too simple.

108 . Sherilynn Young, 'Fertility and Famine: Women's Agricultural History in

Southern Mozambique', in R. Palmer and N. Parsons, Eds., The Roots of Rural Poverty in Central and Southern Africa (London, Heinemann Educational Books 1977), p. 66-81. 
${ }^{109}$.Though Ranger's work in Makoni, see Ranger Peasant Consciousness, challenged the historical accuracy of his account, Arrrighi drew attention to the ways in which the loss of craft production could draw into dependence for commodities in Zimbabwe, see G. Arrighi, 'Labour Supplies in Historical Perspective: A Study of the Proletarianisation of the African Peasantry in Rhodesia', in G. Arrighi and J. Saul, Eds., Essays on the Political Economy of Africa, New York, Monthly Review Press), pp. 180-234. Schmidt's work, Peasants, Traders, and Wives, drew attention to gender differences in technical change in rural production. ${ }^{110}$. See Isaacman, Cotton is the Mother, p. 229ff for discussion of intrahousehold tension under forced cotton cropping.

${ }^{111}$.Sung by Dora Sathani Gwambe, Khambane, Homoine, 11.9.1979, recorded and translated by Alpheus Manghezi, CEA archives.

112. Isaacman, Cotton is the Mother, p 196.

113 . Geffray, 'Transformations historiques.'

114. This may explain overall low yields, but it seems to me an inadequate understanding of the conflicts between cotton and better paying commercial crops, and between cotton and subsistence cultivation, a particularly important question for women, who were the major producers of cotton in the labour-reserve areas.

${ }^{115}$.Isaacman, Cotton is the Mother, Vail and White, 'Forms of Resistance,' and R. First Black Gold. The latter includes only part of a large collection of songs gathered by A. Manghezi with the assistance of S. Zandamela in southern Mozambique (CEA archives).

${ }_{116}$. Isaacman, Cotton is the Mother, p. 224.

117 . Isaacman, Cotton is the Mother, p. 223.

118 . Isaacman, Cotton is the Mother p. 225.

119 . Isaacman, Cotton is the Mother, p. 222.

120. My position here is closer to Henry Bernstein's approach to commoditisation in 'African Peasantries: a Theoretical Framework,' Journal of Peasant Studies (6 , 4, 1979), pp. 421-443, than to his later work with Brass on deproletarianisation, Tom Brass and Henry Bernstein, 'Introduction: Proletarianisation and Deproletarianisation on the Colonial Plantation,' Journal of Peasant Studies (19 (3/4 1992), pp. 1-40. 